\title{
SPACE LAW - THE NEW SUB-BRANCH OF LAW STUDIES IN LATVIA
}

\author{
Jānis Grasis \\ Riga Stradiņš University, Latvia
}

\begin{abstract}
Latvia became an associate member of the European Space Agency (ESA) in 2020. The ESA is an intergovernmental organisation dedicated to the exploration of space. According to the Article II of the Convention of establishment of a European Space Agency, the purpose of the ESA is to promote, for exclusively peaceful purposes, cooperation among European States in space research and technology and their space applications, with a view to their being used for scientific purposes and for operational space applications systems. "The Space Strategy for Latvia 2021-2027” (Strategy) recently was collectively developed by the Ministry of Education and Science and the Ministry of Economics of the Republic of Latvia. It establishes a focused framework for the cooperation of Latvia with the ESA and contributes to the achievement of the objectives, priorities and actions defined in the Latvian National Development Plan 2021-2027, the National Industrial Policy Guidelines 2021-2027 and the Science, Technological Development and Innovation Guidelines 2021-2027. As it is indicated in the Strategy, Latvian higher education institutions ensure the development of an adequate base of expertise and skills in graduates to be able to serve the needs of the space sector in Latvia. It is proposed in Strategy that Universities in collaboration with local industrial partners develop higher-education courses and lifelong learning programmes to respond to the national space industry need. Novelty of the research: this is one of the first academic research concerning the possible studies of space law in the Latvian higher education institutions. Just now law studies are provided by 8 higher education institutions; but no one offers single study course on space law. The research aim is to analyse necessity to teach space law in the universities of the Republic of Latvia, taking into account the fact that Latvia now is an associate member of the ESA. The author has used descriptive, analytical and deductiveinductive research methods in the article. After review and analysis of the legal acts, policy planning documents and different reports, the author has made conclusions and recommendations. Preliminary it seems that space law must be teached as separated study course (or at least this topic must be included in the study course "International air law" or similar study course); publication of teaching book "Space law" also is desirable in latvian language.
\end{abstract}

Keywords: European Space Agency; space law; the Space strategy.

\section{Introduction}

The European Space Agency (hereinafter - ESA) is an intergovernmental organisation dedicated to the exploration of space. According to the Article II of the Convention of establishment of a European Space Agency, the purpose of the 
ESA shall be to provide for, and to promote, for exclusively peaceful purposes, cooperation among European States in space research and technology and their space applications, with a view to their being used for scientific purposes and for operational space applications systems (European Space Agency, 2010). Latvia became an associate member of the European Space Agency (ESA) in 2020: the respective Agreement between the Government of the Republic of Latvia and the ESA was signed on 30 June 2020 (Latvijas Republikas Saeima, 2020); the Saeima (the parliament of the Republic of Latvia) has adopted law ratifying the Agreement on 27 July 2020 (Latvijas Republikas Saeima, 2020). The research aim of the present article is to analyse necessity to teach space law in the universities of the Republic of Latvia, taking into account the fact that Latvia now is an associate member of the ESA. Novelty of the research: this is one of the first academic research concerning the possible studies of space law in the Latvian higher education institutions. Just now law studies are provided by 8 higher education institutions; but no one offers single study course on space law. Descriptive, analytical and deductive-inductive research methods are used. Legal acts, policy planning documents and different reports were reviewed and analyzed, and subsequently conclusions and recommendations were made.

\section{Space Law as the Legal Discipline Literature Review}

Doctor of international law Juris Bojars has overlooked the space law in his first book on international law (Bojars, 1996). Ten pages cover topics such as the concept of space law and the development of space exploration; the main principles of space law, as well as actions in space and the registration of space objects; the legal regime of moon and other celestial bodies, international responsibility for space actions; satellite communications, etc.

Even more briefly, space law issues are also described in the book of A. Fogels on modern international law: the concept and key law sources; the legal status of space and celestial bodies; the legal status of space objects; international responsibility related to space; space communications and cosmic meterology; legal issues for national cooperation and mutual assistance for the exploration and use of space (Fogel, 2009).

Since 2012 Engineering Research Institute „Ventspils International Radio Astronomy Centre" (hereinafter - ERI VIRAC) of the Ventspils University of Applied Sciences (hereinafter - VUAS) publishes once per two years journal "Space Research Review". It is peer-reviewed international journal intended for publication of broad-spectrum original articles, reviews and short communications about actual problems of frontier space technologies: space science, including space and atmospheric physics, Earth observation and remote 
sensing from space, planetary sciences, astrochemistry, astrobiology and life sciences, and spacebased astronomy and astrophysics; space engineering, including communications, navigation, space operations, satellite design, testing, and implementation, engineering of new generation telescopes; space IT solutions, including data acquisition, signal processing, data correlation, parallel and high performance and cloud computing techniques; as well as innovations in space education and training (Ventspils University of Applied Sciences, 2018). The author of the present article did not find any article relating to the space law in "Space Research Review".

It is interesting that some of a very prestigious books on international law do not have chapter on space law at all: for example, book published by Oxford University press, missing chapter on space law (Evans, 2006).

M. Sudārs describes the exploration of space, along with the exploration of the celestial bodies, including the use of space object and space resources in the economy, for meteorological and natural observations, for communication, navigation, as well as for military purposes in the Latvian National Encyclopedia (Sudārs, 2020).

\section{Methodology}

The research object of the article is the role of the universities and the other institutions of higher education and state for providing education in the field of space law. The tasks of the research are the following: 1) to make brief general overview of how the space regulation is taught in other EU universities and possibilities to teach space law in universities and the other institutions of higher education in Latvia; 2) to indicate practical benefits from space industry and its connection with space law studies; 3 ) to elaborate suggestions for introduction of legal studies of space law in universities and the other institutions of higher education in Latvia. Descriptive, analytical and deductive-inductive research methods are used. Legal acts, policy planning documents, literature and different reports were reviewed and analyzed, and subsequently conclusions and recommendations were made. The article is dedicated to issues and perspectives of education in the field of space law and content of such studies in the Republic of Latvia.

\section{Research Results}

As it is indicated by M.N. Shaw, the legal regime of outer space was clarified by the signature in 1967 of the Treaty on Principles Governing the Activities of States in the Exploration and Use of Outer Space, including the Moon and Other Celestial Bodies (hereinafter - Space Treaty). This reiterates that outer space, 
including the moon and other celestial bodies, is not subject to national appropriation by any means and emphasis that the exploration and use of outer space must be carried out for the benefit of all countries. The Space Treaty does not establish as such a precise boundary between airspace and outer space but it provides the framework for the international law of outer space (Shaw, 2003, p.481).

Just now the United States of America, China, the European Union, Russia and other countries are going to make bases on the Moon, and commercial firms are building technology on how space raw materials could be extracted and recycled. Problem: There is no internationally recognised treaty to manage the exploitation and exploitation of space resources. At the same time, there is a growing threat of the militarisation of space, a lack of management agreements and mechanisms to ensure legal and peaceful development. It is important to note that the previous president of United States Mr. Donald Trump had issued even a presidential order stipulating that the United States will act with all the diplomatic means in such a way that the Moon Treaty loses its legitimate power and the U.S. can set the order in space (Beldavs, 2020).

“The Space Strategy for Latvia 2021-2027” (hereinafter - Strategy) recently was collectively developed by the Ministry of Education and Science and the Ministry of Economics of the Republic of Latvia. It establishes a focused framework for the cooperation of Latvia with the ESA and contributes to the achievement of the objectives, priorities and actions defined in the Latvian National Development Plan 2021-2027, the National Industrial Policy Guidelines 2021-2027 and the Science, Technological Development and Innovation Guidelines 2021-2027. As it is indicated in the Strategy, Latvian higher education institutions ensure the development of an adequate base of expertise and skills in graduates to be able to serve the needs of the space sector in Latvia. It is proposed in Strategy that Universities in collaboration with local industrial partners develop higher-education courses and lifelong learning programmes to respond to the national space industry need (The Space Strategy for Latvia 2021-2027, 2020, p.18-19).

Thanks to the associate membership of Latvia in ESA, Latvian business entities start to participate actively in space related business. Already on 15 September 2020, the ESA concluded a contract of total amount of 129.4 million of Euros for the implementation of the first ESA planet defence mission HURA. The project aims to study the effectiveness of the impact of the shock to address potential asteroid threats to humanity in the future. The Latvian company SIA "Eventech" has developed a specialised time measurement module with its international co-operation partners, which measures light flight time in space. The participation of the Latvian company in this world-level mission is possible thanks to the investment of the Ministry of Education and Science in the ESA European 
Cooperation State Plan, in which this technology was developed (LVportals.lv, 2020).

Also ERI VIRAC of VUAS is interested actor in collaboration with ESA as it is a science education center specializing in the field of space technology and signal processing. As we can see from their homepage, the strategic goal of ERI VIRAC is to become a global provider of research services in the field of astronomy and space technology in Latvia (VIRAC, 2021). Member of Saeima V.A. Terauda also have indicated, that cooperation with ESA provide substantial development funding for Latvian scientific institutes. Thus, Latvia has the opportunity to implement space-related scientific projects (Tērauda, 2019). Latvia generally has excellent scientific training for so called STEM disciplines (Science, Technology, Engineering, and Mathematics) which are a very important for space scientific and practical projects (The Space Strategy for Latvia 2021-2027, 2020, p.18-19). Space research includes elements from nearly all science and partly engineering science. Space research-related sciences shall be divided into two groups: (1) natural and engineering necessary for the realisation of space research; and (2) science, which uses space objects for its own research. (Sudārs, 2020). But space sector makes demand also for legal knowledges of space regulation. STEM disciplines need support of space law specialists, starting from issues in connection with spaceports and small satellite constellations, on-orbit servicing and finally with harmful interference, jamming, signal interception and cyber security. As it is indicated by the European Commission, the growing market for space products and services, development of space activities requires to decide on legal issues both at European level and at Member States level in through national law. Still the majority of Member States have not yet developed national space legislation; but we have to recognise that the scope and objectives of such regulation have implications that go beyond national boundaries (Communication, 2013). We need harmonisation of legal framework of national legislation in order to ensure a coherent coverage of space-related legal issues within EU internal market. Such harmonized EU space regulation will prevent diverging national legal frameworks. As an example, some EU Member States have national legislation which foresees the liability for physical damage caused by space activities. Some EU Member States have limits for the liability up to a certain amount, some countries claim an insurance or another financial guarantee to compensate possible damages. Such non-harmonized rules in EU Member States could create distortions of competition on the internal market and lead to "forum shopping"(Communication, 2013). Therefore we need to start space law studies in Latvia in order to prepare qualified lawyers which are able to participate in development of national and EU level space legislation.

The author of the present article made research about study courses in the law faculties concerning space law. Just now law studies are provided by 
8 universities or higher education institutions, but no one offers single study course on space law (Baltijas starptautiskā akadēmija, 2021; Biznesa augstskolas "Turība" Juridiskā fakultāte, 2021; Daugavpils Universitāte, 2021; Ekonomikas un kultūras augstskola 2021; Latvijas Universitātes Juridiskā fakultāte, 2021; Rīgas Juridiskā augstskola, 2021; Rīgas Stradina universitātes Juridiskā fakultāte, 2021; Rēzeknes tehnoloǵiju akadēmija, 2021). According to the information provided by ESA, there are a lot of universities which are providing study courses on space law in European Union.

Table 1 Study Courses in Space Law in Europe

\begin{tabular}{|c|c|}
\hline Country & University or institution \\
\hline AUSTRIA & University of Graz \\
\hline AUSTRIA & University of Vienna \\
\hline BELGIUM & University of Gent \\
\hline BELGIUM & $\begin{array}{l}\text { Interdisciplinary Centre for Space Studies (ICSS), Leuven } \\
\text { Catholic University }\end{array}$ \\
\hline FINLAND & University of Lapland \\
\hline FRANCE & $\begin{array}{c}\text { Institut de Formation Universitaire et de Recherche du } \\
\text { Transport Aérien (IFURTA), University Paul Cézanne, Aix } \\
\text { Marseille III }\end{array}$ \\
\hline FRANCE & $\begin{array}{l}\text { Institute of Space and Telecommunications Law, University } \\
\text { of Paris-Sud XI }\end{array}$ \\
\hline FRANCE & International Space University \\
\hline FRANCE & University of West Brittany, Brest \\
\hline FRANCE & University of Paris I Panthéon - Sorbonne \\
\hline GERMANY & $\begin{array}{l}\text { Institute of Air and Space Law (IASL), University of } \\
\text { Cologne }\end{array}$ \\
\hline HUNGARY & University of Szeged \\
\hline HUNGARY & $\begin{array}{l}\text { Pázmány Péter Catholic University, Faculty of Law and } \\
\text { Political Sciences }\end{array}$ \\
\hline ITALY & University of Padua \\
\hline ITALY & Sapienza University of Rome \\
\hline ITALY & $\begin{array}{l}\text { Italian Society for the International Organization (SIOI), } \\
\text { Rome }\end{array}$ \\
\hline LUXEMBOURG & The University of Luxembourg \\
\hline THE NETHERLANDS & $\begin{array}{c}\text { International Institute of Air \& Space Law (IIASL), Leiden } \\
\text { University }\end{array}$ \\
\hline UNITED KINGDOM & $\begin{array}{l}\text { British Institute of International and Comparative Law } \\
\text { (BIICL), London }\end{array}$ \\
\hline UNITED KINGDOM & London Institute of Space Policy and Law \\
\hline UNITED KINGDOM & $\begin{array}{c}\text { Centre for Law and the Environment: Satellites and the Law, } \\
\text { University College London }\end{array}$ \\
\hline UNITED KINGDOM & University of London \\
\hline
\end{tabular}

Source: European Space Agency (2021). 
As we can see from the Table 1, not only European space exploration superpowers like France, Germany, Italy and United Kingdom provides teaching od space law, but also smaller countries like Austria, Belgium, Finland, Hungary and Luxembourg have study courses on space law in their universities. What are the space law studies content? The author of the present article investigated a several study courses from the above mentioned universities. For illustration I will give small inside of a study course prepared by London Institute of Space Policy and Law, which, in my view, is one of the best.

\section{Table 2 Space Law Studies Content}

\begin{tabular}{|c|c|}
\hline Topic & Content \\
\hline $\begin{array}{l}\text { SPACE ENVIRONMENT } \\
\text { AND TECHNOLOGY }\end{array}$ & $\begin{array}{c}\text { Delimitation of Space and Airspace } \\
\text { Environmental characteristics } \\
\text { Orbits, types of spacecraft, mega-constellations }\end{array}$ \\
\hline $\begin{array}{l}\text { POLICY REGIME, } \\
\text { FORMULATION AND } \\
\text { INSTITUTIONS }\end{array}$ & $\begin{array}{c}\text { Policy Principles, Peaceful Use, Non-appropriation, } \\
\text { Cooperation and Non-interference } \\
\text { Policy development and institutions } \\
\text { International and National Institutions - nature and role } \\
\text { UN COPUOS, ESA, Regional Organisations and Operating } \\
\text { Method }\end{array}$ \\
\hline THE LEGAL REGIME & $\begin{array}{c}\text { Sources of Space Law, Outer Space Treaties, UN } \\
\text { Resolutions; Other regimes - Antarctic, } \\
\text { Maritime and Air Law } \\
\text { International Responsibility and Liability distinguished } \\
\text { National space laws and Licensing } \\
\end{array}$ \\
\hline $\begin{array}{l}\text { THE LAWS GOVERNING } \\
\text { SPACE APPLICATIONS }\end{array}$ & $\begin{array}{c}\text { Sovereignty, Property Rights } \\
\text { Remote Sensing: UN Principles and Disaster Charter } \\
\text { Scientific experiment, Exploration and Exploitation } \\
\text { Manned space activities: The ISS \& its IGA; Chinese Space } \\
\text { Station }\end{array}$ \\
\hline $\begin{array}{c}\text { SATELLITE } \\
\text { COMMUNICATIONS }\end{array}$ & $\begin{array}{c}\text { Telecommunications and Broadcasting: The Role of the ITU } \\
\text { Orbital Positions, Co-ordination } \\
\text { Spectrum management: Frequency Efficiency and Market } \\
\text { Reach } \\
\text { Harmful interference, jamming, signal interception, cyber } \\
\text { security }\end{array}$ \\
\hline $\begin{array}{c}\text { COMMERCIAL SPACE } \\
\text { ACTIVITIES }\end{array}$ & $\begin{array}{c}\text { Nature and range of commercial space ventures } \\
\text { PNT Applications and Services } \\
\text { Spaceflight and Spaceports } \\
\text { Small Satellite Constellations, On-orbit Servicing }\end{array}$ \\
\hline $\begin{array}{l}\text { CURRENT AND FUTURE } \\
\text { DEVELOPMENTS }\end{array}$ & $\begin{array}{c}\text { EU and ESA Relationship } \\
\text { Impact of UK Withdrawal from EU } \\
\text { Space Powers Mid-century, US, China, Russia, India, Japan, } \\
\text { EU }\end{array}$ \\
\hline
\end{tabular}

Source: ISPL (2020). 


\section{Conclusions and Discussions}

1. The participation of the Republic of Latvia in ESA opens up a new opportunities for Latvian universities, research institutions and commercial companies to actively engage in space research, obtain additional financing outside Latvia and demonstrate our knowledge and capacity in this sector.

2. ESA provides excellent scientific training for scientists from so called STEM disciplines (Science, Technology, Engineering, and Mathematics) which are a very important for space scientific and practical projects; simultaneously space sector makes demand also for legal knowledges of space regulation.

3. Just now law studies are provided by 8 universities or higher education institutions in Latvia, but no one offers single study course on space law. The author of the article recommends that space law must be teached as separated study course (or at least this topic must be included in the study course "International air law" or similar study course); whether to teach a study course on space law in one of the faculties of legal education or, for example, in Ventspils University of Applied Sciences, it is a matter of discussion.

4. The study course "Space law" must include the main areas of space law, like sources of space law, Outer space treaties, UN resolutions; delimitation of space and airspace, environmental characteristics, orbits, types of spacecraft, mega-constellations; telecommunications and broadcasting: the role of the ITU, orbital positions, co-ordination spectrum management: frequency efficiency and market reach, harmful interference, jamming, signal interception, cyber security etc.

5. We have some textbooks with chapters about space law in Latvian books on the international law written by J. Bojars and A. Fogels, but the amount of information on space law is not enough. Therefore, in order to develop also space terminology in Latvian language, publication of a new comprehensive teaching book "Space law" also is desirable in Latvian language.

6. At the moment, it is too early to conclude how effective will be membership of the Republic of Latvia in ESA. STEM universities and also law faculties of the Republic of Latvia must contribute to the development of the space industry in Latvia.

\section{References}

Baltijas starptautiskā akadēmija. (2021). Retrieved from: https://bsa.edu.lv/programmas/

Beldavs, V. (2000). Latvija var runāt par likumību kosmosā. Retrieved from: https://ir.lv/2020/09/18/latvija-var-runat-par-likumibu-kosmosa/

Biznesa augstskolas "Turība" Juridiskā fakultāte. (2020). Retrieved from: https://www.turiba.lv/lv/studiju-programmas/bakalaura-programmas/tiesibu-zinatne-

2\#undefined 
Bojārs, J. (1996). Starptautiskās tiesības. Zvaigzne ABC, 330.-340.lpp.

Daugavpils Universitāte (2021) Retrieved from: https://du.lv/fakultates/socialo-zinatnufakultate/studiju-programmas/

Ekonomikas un kultūras augstskola. (2021). Retrieved from: https:/www.augstskola.lv/ ?parent $=156 \& \operatorname{lng}=$ lva

EUR-LEX. (2013). Communication from the Commission to the European Parliament, the Council, the European Economic and Social Committee and the Committee of the Regions. EU Space industrial policy releasing the potential for economic growth in the space sector. Document 52013DC0108. Retrieved from: https://eur-lex.europa.eu/legalcontent/EN/TXT/?uri=celex:52013DC0108

European Space Agency. (2010). Convention for the Establishment of a European Space Agency. ESA Convention and Council Rules of Procedure. European Space Agency, SP1317/EN December 2010.

European Space Agency. (2021). Institutions teaching Space Law. Retrieved from: https://www.esa.int/About_Us/ECSL_-_European_Centre_for_Space_Law/Institutions_ teaching_Space_Law

Evans, M.D. (2006). In Malcolm D. Evans (eds.), International law. Oxford University press.

Fogels, A. (2009). Modernas starptautiskās tiesības. Zvaigzne ABC, 203.-210.lpp.

Latvijas Universitātes Juridiskā fakultāte. (2021). Retrieved from: https://www.jf.lu.lv/ studijas/studentiem/

LR Saeima. (2020). 2020.gada 10.jūnija starptautisks līgums "Latvijas Republikas valdības un Eiropas Kosmosa aǵentūras asociētās dalībvalsts līgums". Retrieved from: https://likumi.lv/ta/id/316032-par-latvijas-republikas-valdibas-un-eiropas-kosmosaagenturas-asocietas-dalibvalsts-ligumu

LR Saeima. (2020). Saeimas 2020.gada 9.jūlija likums "Par Latvijas Republikas valdības un Eiropas Kosmosa aǵentūras asociētās dalībvalsts lìgumu”. Retrieved from: https://likumi.lv/ta/id/316032-par-latvijas-republikas-valdibas-un-eiropas-kosmosaagenturas-asocietas-dalibvalsts-ligumu

London Institute of Space Policy and Law (ISPL). (2020). SPACE POLICY \& LAW COURSE. Retrieved from: https://www.space-institute.org/app/uploads/1603386043_ISPL_2020_ Space_Policy_and_Law_Course_Tutors_\&_Sessions.pdf

LVportals.lv. (2020). Latvijas uzñèmums piedalās pirmajā Eiropas Kosmosa à́entūras planētas aizsardzības misijā. Retrieved from: https://lvportals.lv/dienaskartiba/320005latvijas-uznemums-piedalas-pirmaja-eiropas-kosmosa-agenturas-planetas-aizsardzibasmisija-2020

Ministry of Education and Science and Ministry of Economics of the Republic of Latvia. (2020). The Space Strategy of Latvia 2021-2027. Retrieved from: https://irpcdn.multiscreensite.com/0502f3c5/files/uploaded/the-space-strategy-of-latvia-20212027.pdf

Rīgas Juridiskā augstskola. (2021). Retrieved from: https://www.rgsl.edu.lv/lv/programmas

Rīgas Stradiṇa universitātes Juridiskā fakultāte. (2021). Retrieved from: https://www.rsu.lv/ juridiska-fakultate

Rēzeknes tehnolog̣iju akadēmija. (2021). Retrieved from: https://www.rta.lv/sv_tiesibu_ zinatne

Shaw, M.N. (2003). Air law and Space law. In Shaw M.N., International law, (463-489). Cambridge University Press.

Sudārs, M. (2020). Kosmosa izpēte. Retrieved from: https://enciklopedija.lv/skirklis/943kosmosa-izp\%C4\%93te 
Tērauda, V.A. (2019). Latvijas dalība Eiropas Kosmosa ağentūrā ir būtisks ieguvums Latvijas zinātnei. Retrieved from: https://lvportals.lv/dienaskartiba/310940-v-a-terauda-latvijasdaliba-eiropas-kosmosa-agentura-ir-butisks-ieguvums-latvijas-zinatnei-2019

Ventspils University of Applied Sciences. (2018). Space Research Review, Volume 5.

VIRAC. (2021). About VIRAC. Retrieved from: https://www.virac.eu/en/about 